\title{
Optimization of Mechanical Properties of High-Carbon Pearlitic Steels with SI and V Additions
}

\author{
K. HAN, D.V. EDMONDS, and G.D.W. SMITH
}

Systematic research has been undertaken on the effects of single and combined additions of vanadium and silicon on the mechanical properties of pearlitic steels being developed for wire rod production. Mechanical test results demonstrate that the alloy additions are beneficial to the mechanical properties of the steels, especially the tensile strength. Silicon strengthens pearlite mainly by solid-solution strengthening of the ferrite phase. Vanadium increases the strength of pearlite mainly by precipitation strengthening of the pearlitic ferrite. When added separately, these elements produce relatively greater strengthening at higher transformation temperatures. When added in combination the behavior is different, and substantial strength increments are produced at all transformation temperatures studied $\left(550{ }^{\circ} \mathrm{C}\right.$ to $\left.650{ }^{\circ} \mathrm{C}\right)$. The addition of silicon and vanadium to very-high-carbon steels $(>0.8 \mathrm{wt}$ pct C) also suppresses the formation of a network of continuous grain-boundary cementite, so that these hypereutectoid materials have high strength coupled with adequate ductility for cold drawing. A wiredrawing trial showed that total drawing reductions in area of 90 pct could be obtained, leading to final tensile strengths of up to $2540 \mathrm{MPa}$ in 3.3-mm-diameter wires.

\section{INTRODUCTION}

THE primary requirements for high-strength wire applications are tensile strength, ductility, and formability. Colddrawn plain-carbon pearlitic steels have commonly been employed for this purpose. The properties of such drawn wires are a function of the strength and microstructure of the feedstock, the amount of reduction during drawing, and the geometry of the dies. It is known that there are limitations on the strength that can be achieved in as-patented plaincarbon steels through changes of the heat-treatment conditions, amount of cold deformation, die geometry, and temperature of the drawn wire (dynamic aging and static aging). Although very-fine-diameter pearlite wire has achieved very high strength, ${ }^{[1,2]}$ it is difficult to draw plain-carbon steels into wire of a strength higher than $2000 \mathrm{MPa}$ with a large finished diameter $(>2 \mathrm{~mm})$. A relatively larger rod feedstock diameter is necessary, and this makes it difficult to achieve the rapid transformation conditions needed to produce the finest pearlite spacings and, hence, to obtain the highest rod strengths. Also, drawing a larger cross section rod introduces nonuniform deformation and may even cause premature failure when processing plain-carbon steels. Similar problems are also found in drawing large-cross section nonferrous composites. ${ }^{[3]}$ The other method to increase the strength of the wire, if a large final cross section is required, is to increase the tensile strength of the rod prior to cold drawing. This permits a desired final wire tensile strength to be achieved with a smaller overall drawing strain. The most efficient ways to develop such a high-strength rod from the customary pearlite microstructure are to add alloy elements or increase the carbon content.

K. HAN, Research Scientist, is with the National High Magnetic Field Laboratory, Florida State University, Tallahassee, FL 32308. D.V. EDMONDS, Professor, is with the School of Engineering, University of Leeds, Leeds, LS2 9JT, United Kingdom. G.D.W. SMITH, Professor, is with the Department of Materials, Oxford University, Oxford, OX1 3PH, United Kingdom.

Manuscript submitted June 5, 2000.
If the carbon content is increased to higher than $0.8 \mathrm{wt}$ pct, continuous grain-boundary cementite can form and cause embrittlement. ${ }^{[4,5]}$ Nevertheless, we have found that it is possible to use pearlitic steels with carbon contents greater than $0.8 \mathrm{wt}$ pet without the formation of a continuous cementite network by the addition of silicon and vanadium together. ${ }^{[6,7]}$ The addition of vanadium results in the fragmentation of the grain-boundary cementite network, and the presence of silicon acts as a kinetic inhibitor to cementite growth during transformation. The addition of vanadium is also beneficial to the stability of the cold-drawn pearlite. The interstitial atoms, especially nitrogen, dissolved in ferrite may cause a significant reduction of the ductility of the steels because of strain aging. ${ }^{[8,9]}$ By the addition of vanadium, the nitrogen dissolved in ferrite ${ }^{[10]}$ can be removed by the formation of alloy carbonitrides, and the strain aging of the wire is minimized.

The addition of alloying elements challenges the conventional concept in wire manufacturing that the optimum microstructure for producing the highest strength in the finished product by cold drawing is the finest possible interlamellar spacing in pearlite. Only a very small amount of alloy addition (e.g., $0.1 \mathrm{wt}$ pct vanadium) may introduce extra strengthening features such as interphase precipitation to the lamellar structure, under certain transformation conditions. ${ }^{[7]}$ Therefore, it is necessary to assess what the optimum microstructure and heat-treatment conditions are in order to achieve the required mechanical properties in such microalloyed steels.

The present work was carried out in order to identify the role of carbon, silicon, and vanadium on the mechanical properties of pearlitic steels. Small, high-purity laboratory melts were first used to investigate the properties of a range of different alloys. Various austenitization conditions were examined, together with a range of isothermal transformation temperatures and times. Based on the information obtained from microstructural examination and hardness tests, an alloy with the best combination of properties was selected for a wire-drawing trial involving two larger heats. This trial 
Table I. Composition of the Experimental Alloys

\begin{tabular}{|c|c|c|c|c|c|}
\hline Alloy & $\mathrm{C}(\mathrm{wt}$ pct \pm 0.02$)$ & $\mathrm{Mn}(\mathrm{Wt}$ Pct \pm 0.02$)$ & $\mathrm{Si}($ Wt Pct \pm 0.02$)$ & $\mathrm{V}(\mathrm{Wt}$ Pct \pm 0.02$)$ & $\mathrm{N}(\mathrm{Wt}$ Pct \pm 0.0005$)$ \\
\hline 1 & 0.76 & 0.72 & 0.23 & - & - \\
\hline 2 & 0.81 & 0.72 & 0.96 & - & - \\
\hline 3 & 0.84 & 0.73 & 1.01 & 0.1 & - \\
\hline 4 & 0.79 & 0.62 & 0.22 & 0.2 & - \\
\hline 5 & 0.82 & 0.66 & 0.91 & 0.2 & - \\
\hline 6 & 0.95 & 0.80 & 0.27 & $<0.02$ & - \\
\hline 7 & 0.95 & 0.77 & 1.04 & $<0.02$ & - \\
\hline 8 & 0.97 & 0.68 & 0.98 & 0.1 & - \\
\hline 9 & 0.96 & 0.68 & 0.96 & 0.2 & - \\
\hline 10 & 0.93 & 0.81 & 1.02 & 0.25 & 0.0095 \\
\hline 11 & 0.95 & 0.82 & 1.04 & 0.22 & 0.0097 \\
\hline 12 & 1.05 & 0.73 & 1.02 & 0.19 & - \\
\hline 13 & 1.15 & 0.88 & 0.39 & - & - \\
\hline 14 & 1.15 & 0.60 & 0.23 & 0.15 & - \\
\hline
\end{tabular}

was carried out in conjunction with Haggie Rand Ltd. (South Africa) and included mechanical tests of as-transformed rod, in order to determine the optimum heat-treatment condition for subsequent wire drawing.

\section{EXPERIMENTAL}

The compositions of the steels used in this work are listed in Table I. (Note: all compositions are quoted in weight percent throughout this article.) The experimental steels 1 through 9 and 12 through 14 were designed to study the effects of silicon and vanadium alloying additions, both separately and in combination, on the hardness and strength of pearlitic steels having carbon contents in the range from 0.76 to $1.15 \mathrm{wt}$ pct. Small $(1 \mathrm{~kg})$ casts were prepared by vacuum melting at Sheffield University Materials Advisory Center, ( , United Kingdom). These were then hot rolled into the form of 12-mm-diameter rods. Microstructural examination of alloys 1 through 9 and 12 has been reported previously. ${ }^{[6,7]}$ Steel 13 was supplied as a $25 \mathrm{~mm}$ bar by G.K.N. Group Technology Centre (Wolverhampton, United Kingdom) and steel 14 was prepared as a small ingot in the Department of Materials at Cambridge University (Cambridge, United Kingdom).

Larger $(40 \mathrm{~kg})$ casts of steels 10 and 11 were prepared by vacuum melting at Iscor Research Laboratory (South Africa) and were hot rolled into the form of 9-, 10-, and 11.5-mm-diameter rods. The compositions of these larger casts were selected following the laboratory work undertaken on steels 1 through 9 and 12 through 14. This showed that if the carbon composition exceeded $1.05 \mathrm{wt}$ pct, the drawability of the steels transformed at relatively low temperatures was likely to be poor, because platelet cementite was present at grain boundaries. Moreover, as carbon segregation was considered to be inevitable in commercial rod steels, the carbon concentration in the segregated region could be well above the maximum design level (i.e., $>1.05$ wt pct). The carbon content of the two larger heats of steel was, thus, chosen as 0.95 wt pct.

The homogenizing heat treatments of the small samples ( $<5 \mathrm{~mm}$ in diameter) were undertaken by sealing the samples in silica tubes with Ti turnings and low-pressure argon gas in order to prevent decarburization and oxidation during heat treatment. Flowing argon/nitrogen gas was used in the furnace during the austenitization of the large samples (up to $10 \mathrm{~mm}$ in diameter.) After air cooling to room temperature, the specimens were reaustenitized at selected temperatures, which were generally chosen to dissolve the alloy carbide in the steels but maintain a relatively small austenite grain size (ASTM grain-size number higher than 3 for vanadium steels). In the case of small-scale laboratory treatments, specimens were then quenched into a salt pot or a lead bath. A continuous industrial patenting line was used for the largerscale trial of steel $11(0.95 \mathrm{C}-1.04 \mathrm{Si}-0.22 \mathrm{~V})$.

The specimens used for hardness tests were $5 \mathrm{~mm}$ in diameter and $20 \mathrm{~mm}$ in length. The experimental samples were taken from regions at least $40 \mathrm{~mm}$ from either end of the hot-rolled rods, in order to avoid inhomogeneity effects. After heat treatment, each specimen was machined to remove the outer surface layers. The hardness measurements were taken from surfaces polished for optical microscopy without being etched, using a Vickers hardness machine equipped with a pyramidal indenter. The minimum impression spacing (center to edge of adjacent impression) was about 2.7 times the diagonal and at least $1 \mathrm{~mm}$ from the edge of the specimen. The loads were applied parallel to the wire axis. Six indentations were obtained from each specimen using a 20 or 30 $\mathrm{kg}$ load. The measured sizes of the indentation were translated into Vickers hardness numbers (HV) from a table according to ASTM Specification E92 ${ }^{[11]}$ and are reported with hardness number first and with the load used second. When the load is omitted from the data, $20 \mathrm{~kg}$ was used.

The specimens used for standard tensile testing were machined axially from rolled bars and had an $18 \mathrm{~mm}$ gage length and $3.5 \mathrm{~mm}$ gage diameter. The specimens were ground and polished to the final required diameter with a 1 $\mu \mathrm{m}$ diamond-paste cloth after heat treatment. Tensile testing was done at room temperature in an Instron machine at an initial strain rate of approximately $5 \times 10^{-4} / \mathrm{s}$. A number of tensile specimens, having lengths of approximately 200 $\mathrm{mm}$ and various gage diameters without shoulders, were also machined from rolled bars and drawn wires. Two tensile tests were carried out for each of the various sizes of wire, with the exception that ten tensile tests were undertaken for the final 2.8-mm-diameter wires.

Samples for transmission electron microscopy (TEM) and 
scanning transmission electron microscopy were prepared by jet polishing. ${ }^{[7]}$ The foils were examined in a PHILIPS*

*PHILIPS is a trademark of Philips Electronic Instruments Corp., Mahwah, NJ.

CM12 analytical electron microscope operating at $120 \mathrm{kV}$.

The interlamellar spacing in pearlitic steels was measured by choosing pearlite colonies with the interface between cementite and ferrite approximately parallel to the electron beam. The specimen was then tilted until the interfaces were parallel to the electron beam. The spacings were finally measured from this area. More than 200 lamellae were measured for each condition.

The wire-drawing trials were carried out at Haggie Rand Ltd. and were divided into two parts: single-die trials and continuous-drawing trials. Rods of $11.5,10$, and $9 \mathrm{~mm}$ diameters were used. The patented 11.5 and $10 \mathrm{~mm}$ rods were drawn using a single-hole die-drawing bench, and the 9mm-diameter rods were drawn via a Veetrac continuous wire-drawing machine. In the Veetrac machine, the $9 \mathrm{~mm}$ rod was first drawn into a 4.26-mm-diameter wire through eight successive dies and was collected. The wire was then drawn into the final product through six further passes. The drawing speed was kept low (approximately $1 \mathrm{~m} / \mathrm{s}$ ) in order to minimize the heat produced by the drawing process. A water cooling device was also employed, in order to reduce further the heat generated in the wires.

\section{RESULTS}

\section{A. Alloying Addition Effects}

The hardness variations of steels with different carbon and alloying-element contents, for different isothermal transformation conditions, are shown in Figures 1 through 3. All the samples were $5 \mathrm{~mm}$ in diameter and were austenitized for 10 minutes at $1050{ }^{\circ} \mathrm{C}$ and subsequently transformed to pearlite in a salt pot held at temperatures between $550{ }^{\circ} \mathrm{C}$ and $650{ }^{\circ} \mathrm{C}$.

Figure 1 shows the hardness variations with transformation temperature and silicon content in different steels. It is apparent that the hardness values increase with increasing silicon content at all isothermal transformation conditions. For example, in Figure 1(a), the addition of $0.75 \mathrm{wt}$ pct silicon increases the hardness of plain-carbon eutectoid steels by about 7 pct in the steels isothermally transformed at $600{ }^{\circ} \mathrm{C}$ (adjusting the data for the slight difference in carbon content between the two steels shown-refer to Section IV-A). The hardness increment due to silicon is larger at the higher transformation temperatures in the case of the plain-carbon eutectoid steels. Figure 1(b) gives the hardness values for two vanadium eutectoid steels having different silicon contents. A greater hardness increment by silicon addition appears to be achieved at the lower transformation temperatures in the vanadium-containing steels, with a marked discontinuity in behavior below $600{ }^{\circ} \mathrm{C}$. Figure $1(\mathrm{c})$ demonstrates the effect of silicon in hypereutectoid plaincarbon steels. As in the case of eutectoid plain-carbon steels, silicon has a greater effect on hardness in the higher-transformation-temperature range.

The effects of vanadium on hardness are shown in Figure 2. It is apparent that, for the same percentage addition by

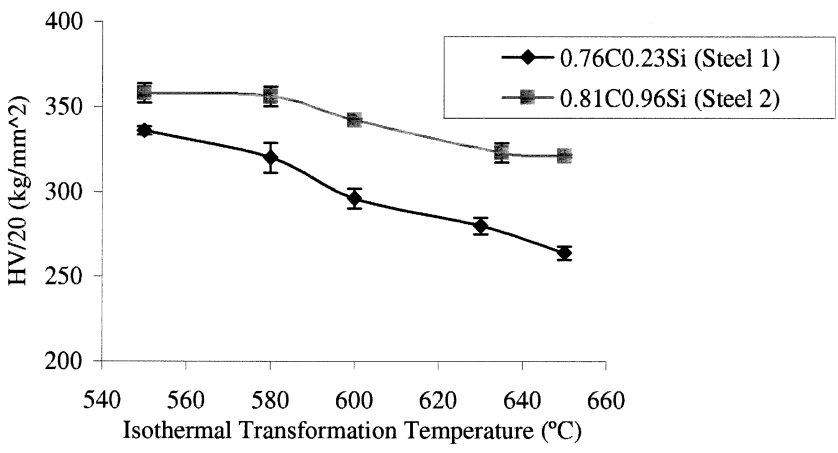

(a)

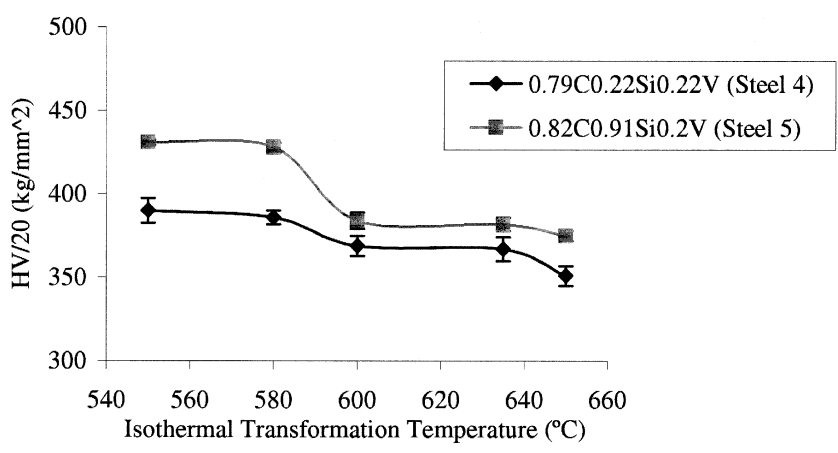

(b)

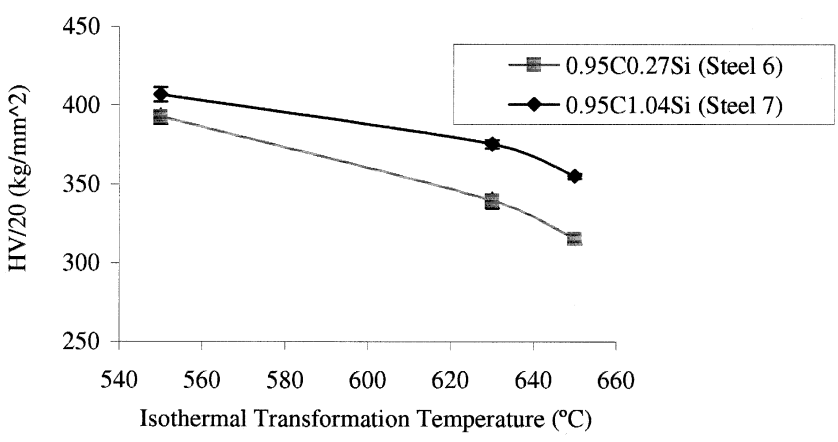

(c)

Fig. 1-Influence of silicon additions on hardness: (a) eutectoid plain carbon steel, $(b)$ vanadium steel, and $(c)$ hypereutectoid steel. The steels were austenitized at $1050{ }^{\circ} \mathrm{C}$ for $10 \mathrm{~min}$ before isothermal transformation at various temperatures for $3 \mathrm{~min}$.

weight, vanadium has a much greater strengthening effect than silicon. For instance, at $580{ }^{\circ} \mathrm{C}, 0.2 \mathrm{wt}$ pct vanadium increases the hardness by about 15 pct for a low-silicon steel $(0.23$ wt pct $\mathrm{Si})$ and by about 20 pct for a high-silicon steel $(0.96 \mathrm{wt}$ pct $\mathrm{Si})$. The variation in hardness with temperature is more complicated in vanadium steels than in the other steels, due to the fact that, as the isothermal transformation temperature is lowered, there is a progressive reduction in interlamellar spacing, coupled with a change in the size and amount of vanadium carbide precipitation. The experimental evidence indicates that as the transformation temperature is lowered, there is a greater strengthening effect by the refinement of the interlamellar spacing of the pearlite, but a lesser effect by interphase precipitation in the pearlitic ferrite. ${ }^{[12]}$ The extent of the decrease in hardness with increasing transformation temperature in a hypereutectoid 


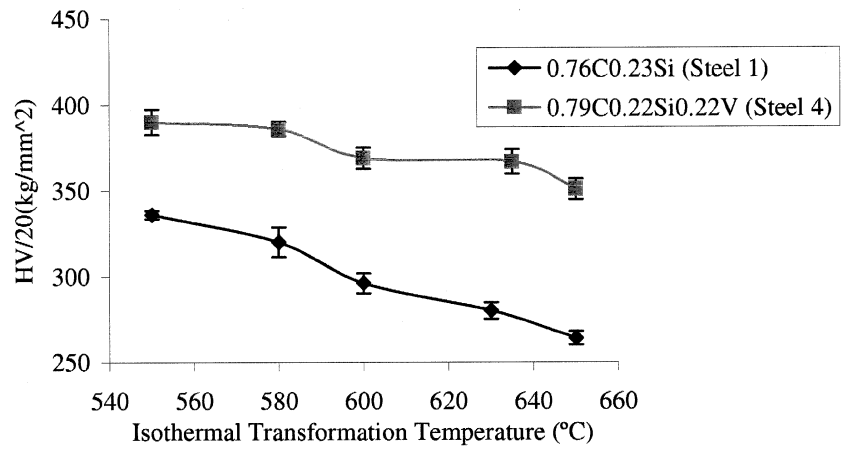

(a)

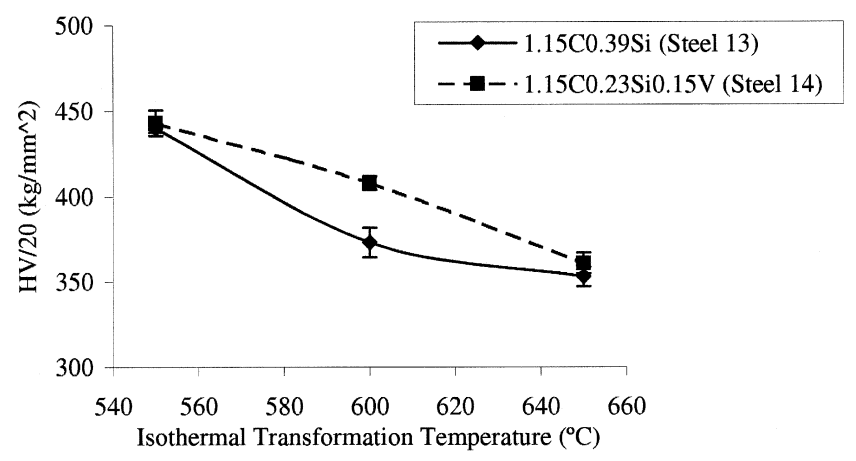

(c)

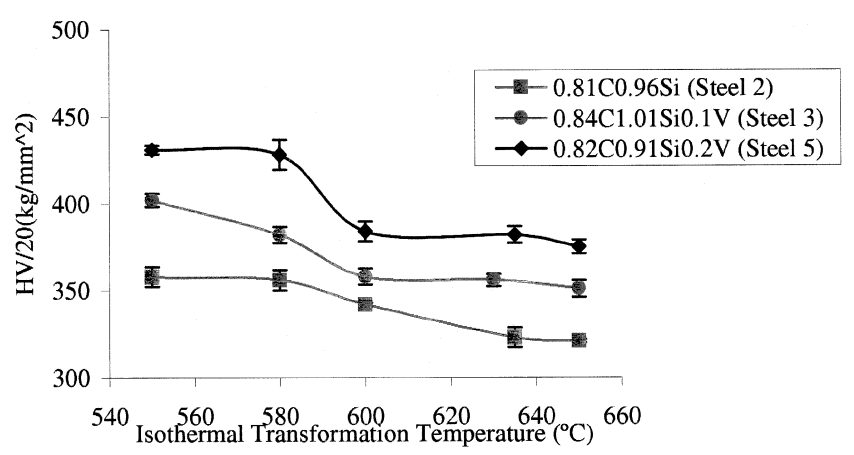

(b)

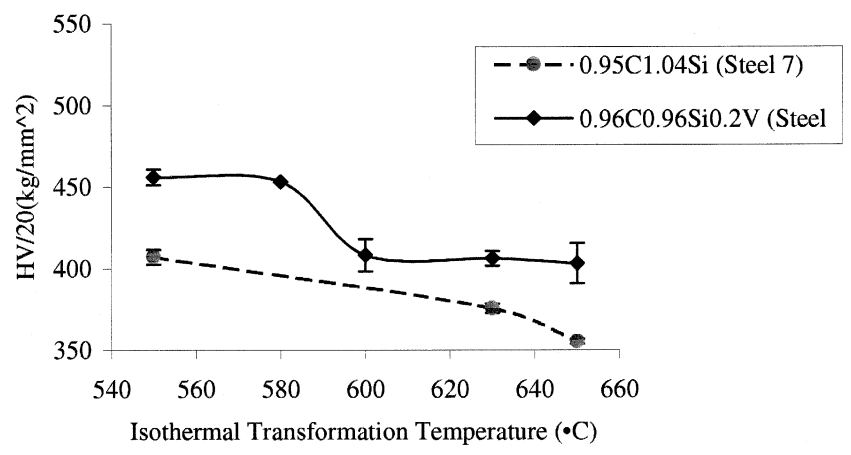

(d)

Fig. 2-Influence of vanadium additions on hardness: $(a)$ eutectoid plain carbon steels, $(b)$ silicon steels, $(c)$ hypereutectoid steels, and $(d)$ silicon hypereutectoid steels. The steels were austenitized at $1050{ }^{\circ} \mathrm{C}$ for $10 \mathrm{~min}$ before isothermal transformation at various temperatures for $3 \mathrm{~min}$.

vanadium steel $14(1.15 \mathrm{C}-0.23 \mathrm{Si}-0.15 \mathrm{~V})$ is very similar to that for a hypereutectoid plain-carbon steel 13 (1.15C0.39Si), as shown in Figure 2(c). Perhaps surprisingly, vanadium appears to have only a limited strengthening effect at this ultrahigh-carbon level (1.15 wt pct C). However, it is possible that in this case the austenization temperature used $\left(1050{ }^{\circ} \mathrm{C}\right)$ may not have been sufficient to dissolve all the primary vanadium carbides.

At lower transformation temperatures $\left(<600{ }^{\circ} \mathrm{C}\right)$, the combination of silicon and vanadium additions has a greater strengthening effect than the sum of the effects of their separate additions. For example, after allowing for the slight differences in carbon contents between the steels studied, the sum of the strengthening effects produced at $550{ }^{\circ} \mathrm{C}$ by individual additions of $0.75 \mathrm{wt}$ pet $\mathrm{Si}$ and $0.2 \mathrm{wt}$ pet $\mathrm{V}$ is about 10 pct, whereas the increment produced by adding the same amount of these elements in combination is about 15 pct. This may be explained by the effect of silicon on reducing the solubility product of vanadium carbide in austenite, which promotes rapid precipitation during the transformation to pearlite. ${ }^{[13]}$

Figure 3 shows the effects of carbon content on the hardness of the steels. As expected, increasing the level of carbon gives extra hardness. For example, at $600{ }^{\circ} \mathrm{C}$, increasing the carbon content from 0.84 to 0.97 pct increases the hardness by 10 pet in 1 pet Si-0.1 pet V steels. In 1 pct Si-0.2 pet V steels, increasing the carbon content from 0.82 to 0.96 pct produces a rather smaller hardness increment (6 pct), and a further increase of carbon content beyond 0.96 pct produces only a very limited further increase. As mentioned earlier, this may be due to incomplete dissolution of vanadium carbide precipitates in ultrahigh-carbon steels during austenitization at $1050{ }^{\circ} \mathrm{C}$.

\section{B. Transformation-Temperature Effects}

The hardness increases with decreasing isothermal transformation temperature for all the alloys studied, as shown in Figures 1 through 3. Thus in principle, lower transformation temperatures should be selected in order to obtain maximum strength. However, the microstructural investigation reported by the present authors for a similar series of alloys ${ }^{[7]}$ indicated that a nonuniform microstructure started to form below $600{ }^{\circ} \mathrm{C}$ in microalloyed pearlites, although no bainite was observed in the temperature range investigated. For example, Figure 4 shows grain-boundary regions in steel 5 (0.82C-0.91Si-0.21V) transformed at $580{ }^{\circ} \mathrm{C}$ and $650{ }^{\circ} \mathrm{C}$, respectively. Very irregular pearlite morphologies are observed at the lower transformation temperature, and these would be expected to have a deleterious effect on wiredrawing properties. In order to avoid this nonuniform microstructure but still obtain the best possible strength, $600{ }^{\circ} \mathrm{C}$ was chosen as the optimum isothermal transformation condition for drawing trials.

The results of mechanical testing of 11.5 -mm-diameter rod samples from the larger-scale heat of steel $10(0.93 \mathrm{C}$ $1.02 \mathrm{Si}-0.25 \mathrm{~V}$ ) are shown in Figures 5 and 6 . The specimens were austenitized for 10 minutes at temperatures in the range from $950{ }^{\circ} \mathrm{C}$ to $1050{ }^{\circ} \mathrm{C}$ and then isothermally transformed in a lead bath at temperatures in the range from $580{ }^{\circ} \mathrm{C}$ to $640{ }^{\circ} \mathrm{C}$. The hardness and ultimate tensile strength both 


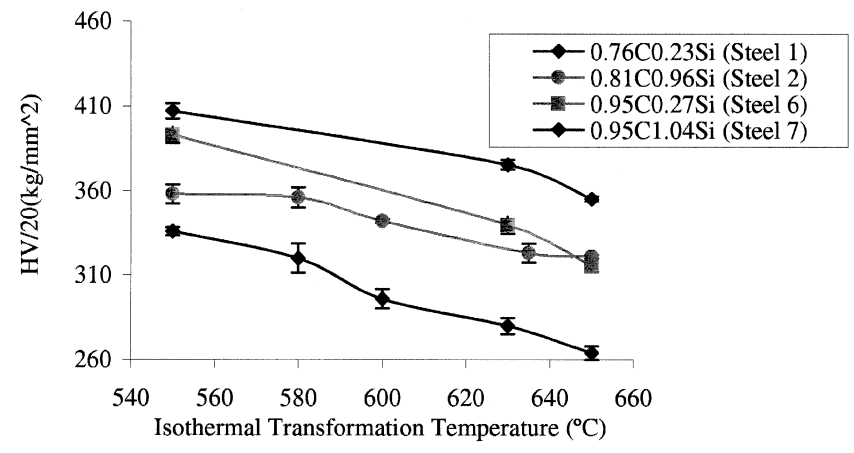

(a)
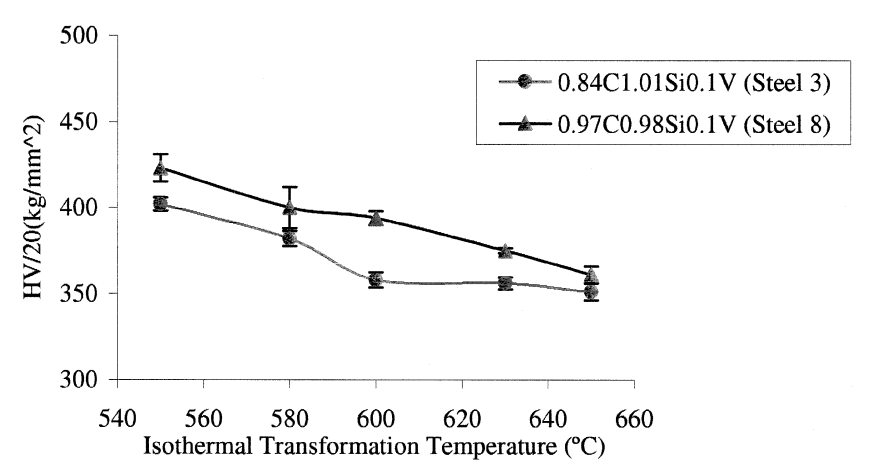

(b)

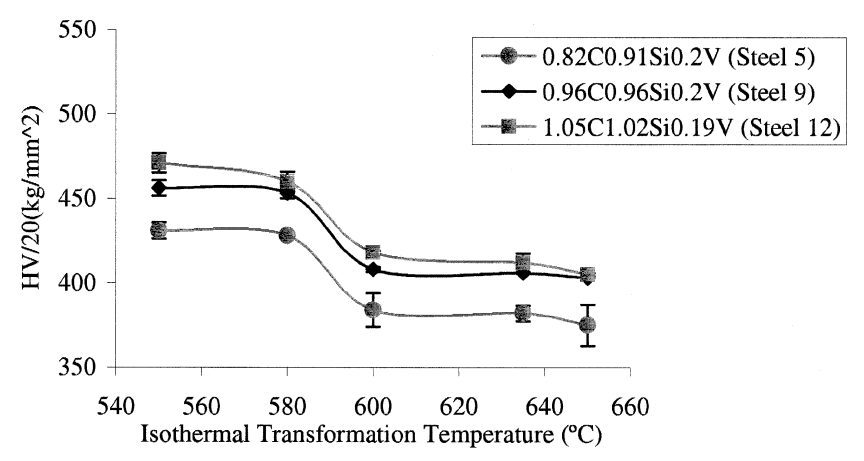

(c)

Fig. 3-Influence of carbon additions on hardness: (a) plain carbon and silicon steels, $(b)$ silicon low vanadium steels, and $(c)$ silicon plus vanadium steels. The steels were austenitized at $1050^{\circ} \mathrm{C}$ for $10 \mathrm{~min}$ before isothermal transformation at various temperatures for $3 \mathrm{~min}$.

increase with decreasing isothermal transformation temperature (Figures 5 and 6(a)). This tendency is the same as that observed during the earlier testing of smaller $(5-\mathrm{mm}$ diameter) samples of the experimental steels shown in Figures 1 through 3 . The hardnesses obtained from the largerscale heat of steel 10 are systematically greater (by 5 to 10 pct) than those recorded for the closest equivalent smallscale experimental steel $9(0.96 \mathrm{C}-0.96 \mathrm{Si}-0.2 \mathrm{~V})$. This may be partly due to the higher vanadium content in the largerscale heat $(0.25$ pct $v s 0.20$ pct), but minor differences in processing and isothermal transformation conditions may also have had an effect. ${ }^{[14]}$

The reduction in area increases with decreasing isothermal transformation temperature when the isothermal transformation temperature is higher than $600{ }^{\circ} \mathrm{C}$ (Figure 6(b)). As the temperature is lowered below $600{ }^{\circ} \mathrm{C}$, the reduction in area starts to drop. As the reduction in area is related to the

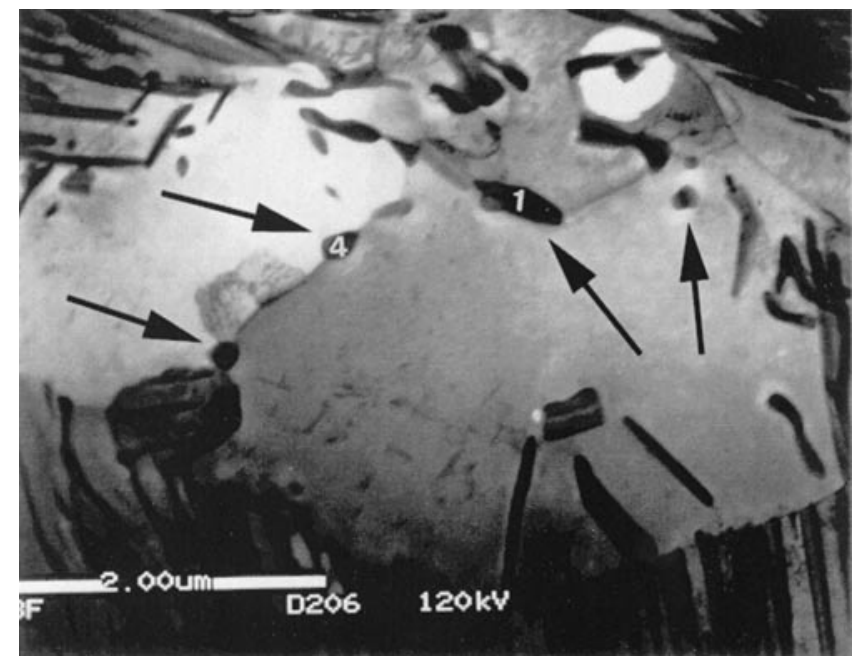

(a)

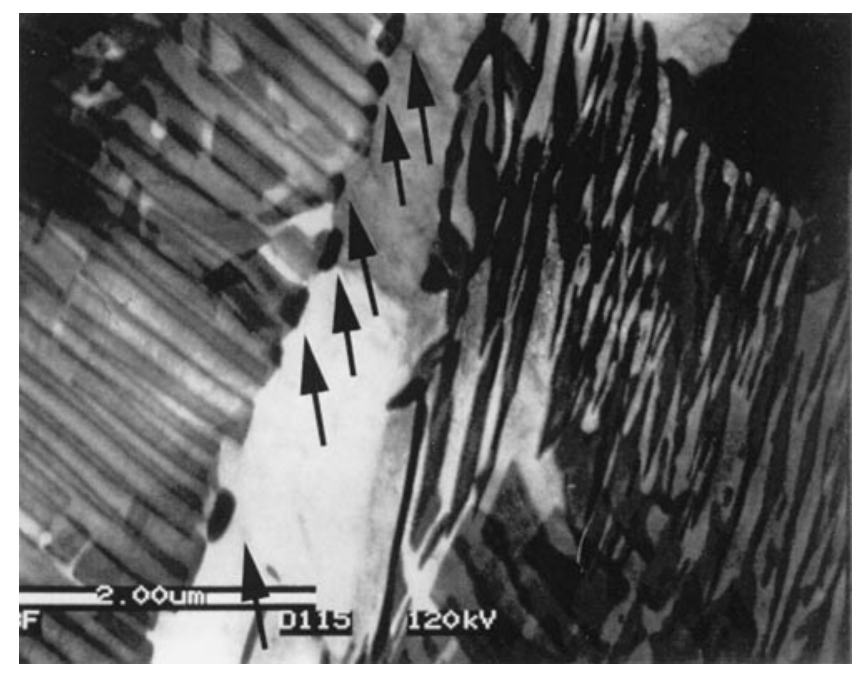

(b)

Fig. 4-Comparison of the microstructure at the vicinity of prior austenite grain boundaries (scanning transmission electron microscopy image) of steel $5(0.82 \mathrm{C}-0.92 \mathrm{Si}-0.2 \mathrm{~V})$ transformed at different temperatures. Arrows indicate grain boundary cementite particles: (a) $580{ }^{\circ} \mathrm{C}$ and $(b) 650{ }^{\circ} \mathrm{C}$.

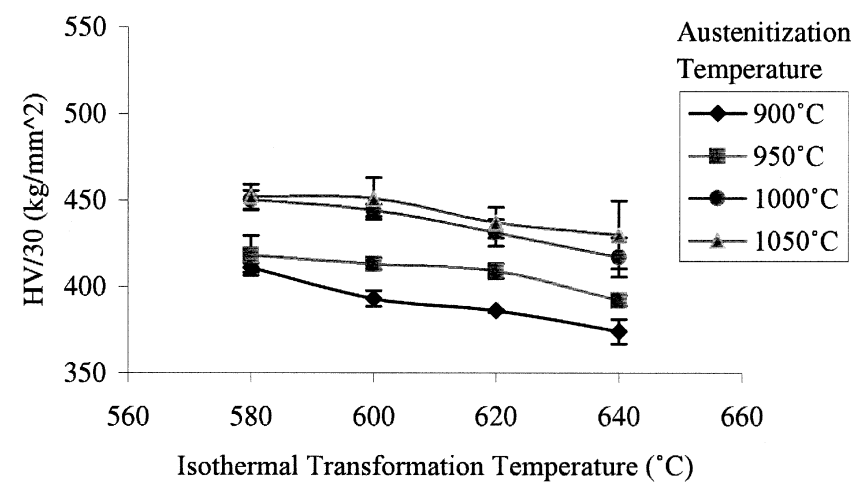

Fig. 5-Hardness test results of 11.5-mm-diameter rod of steel 10(0.93C$1.02 \mathrm{Si}-0.25 \mathrm{~V}$ ) under different austenitization and isothermal transformation temperatures.

drawability of the steels, this confirms that the optimum isothermal transformation temperature of these alloys is 


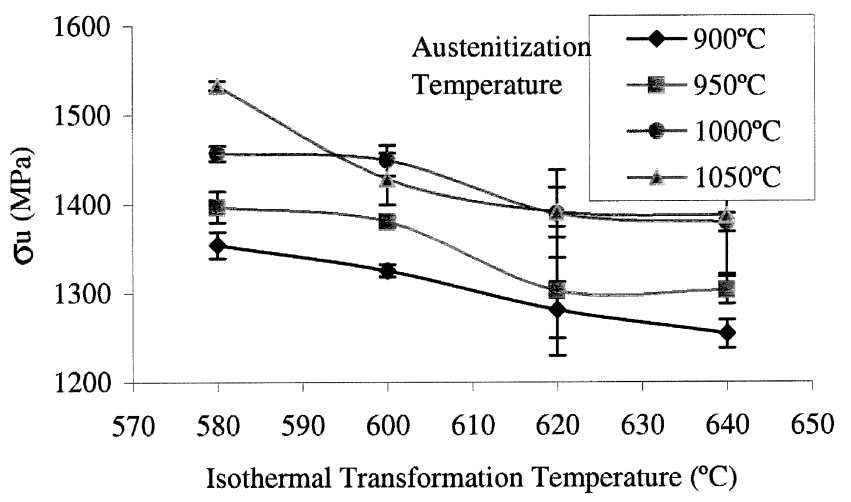

(a)

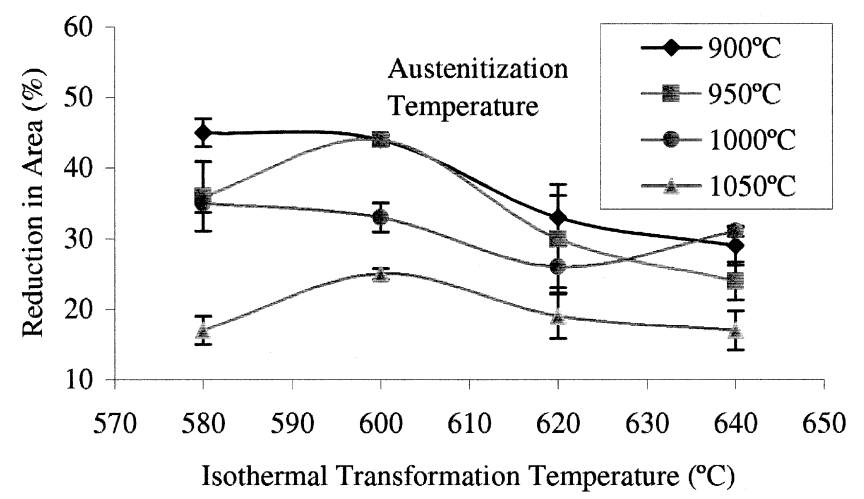

(b)

Fig. 6-Tensile test results of 11.5 -mm-diameter rod of steel $10(0.93 \mathrm{C}$ $1.02 \mathrm{Si}-0.25 \mathrm{~V}$ ) after austenitization at different temperatures for $10 \mathrm{~min}$ and isothermal transformation at different temperatures for 3 min: (a) tensile strength and $(b)$ reduction in area at fracture.

about $600{ }^{\circ} \mathrm{C}$. Figures 5 and 6 also show that the tensile strength and hardness gradually improve with increasing austenitization temperature. This is presumably because the increase of vanadium solubility in the austenite makes more available for subsequent precipitation strengthening. However, above $1000{ }^{\circ} \mathrm{C}$, the ductility decreases dramatically (Figure 6(b)). The best austenitization temperature range is, thus, determined to be between $950{ }^{\circ} \mathrm{C}$ and $1000{ }^{\circ} \mathrm{C}$. The tensile strength of the steel austenitized at $950{ }^{\circ} \mathrm{C}$ was thought to be too low to develop ultrahigh-strength steel wires. Therefore, $1000{ }^{\circ} \mathrm{C}$ was chosen to carry out austenitization on the steels for subsequent drawing trials.

\section{Transformation-Time Effects}

The effects of varying isothermal transformation times on the mechanical properties of steel $11(0.95 \mathrm{C}-1.04 \mathrm{Si}-0.22 \mathrm{~V})$ are illustrated in Figure 7. The specimens were $9 \mathrm{~mm}$ in diameter, the isothermal transformation temperature was 600 ${ }^{\circ} \mathrm{C}$, and the austenitization condition was $1000{ }^{\circ} \mathrm{C}$ for 6 minutes. After a transformation time of 1 minute, a small amount of martensite was found and the ductility was poor. A transformation time of 2 minutes appears to give the optimum balance of properties for a $9 \mathrm{~mm}$ rod, although the ductility was slightly lower than after transformation for 3 minutes.

The effects of varying austenitization times on the mechanical properties of steel $11(0.95 \mathrm{C}-1.04 \mathrm{Si}-0.22 \mathrm{~V})$ were

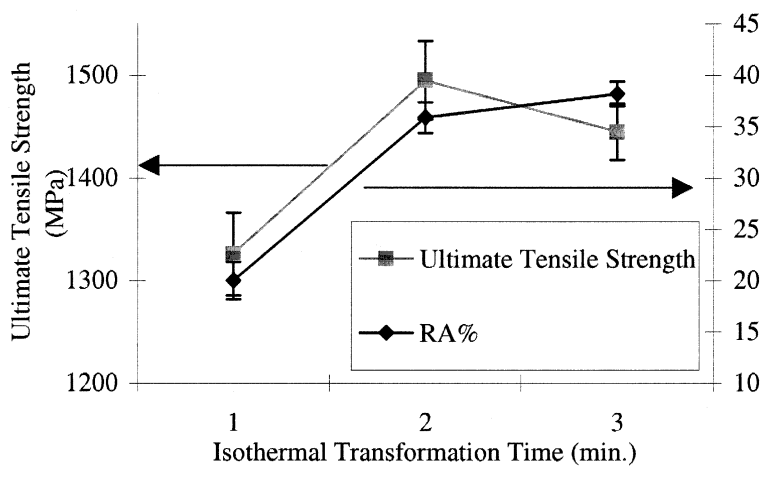

$\stackrel{\overbrace{}}{\varrho}$

Fig. 7 -Tensile test results of steel $11(0.95 \mathrm{C}-1.04 \mathrm{Si}-0.22 \mathrm{~V})$ in 9 -mm rods for different isothermal transformation times at $600{ }^{\circ} \mathrm{C}$ after austenitization at $1000{ }^{\circ} \mathrm{C}$ for $6 \mathrm{~min}$.

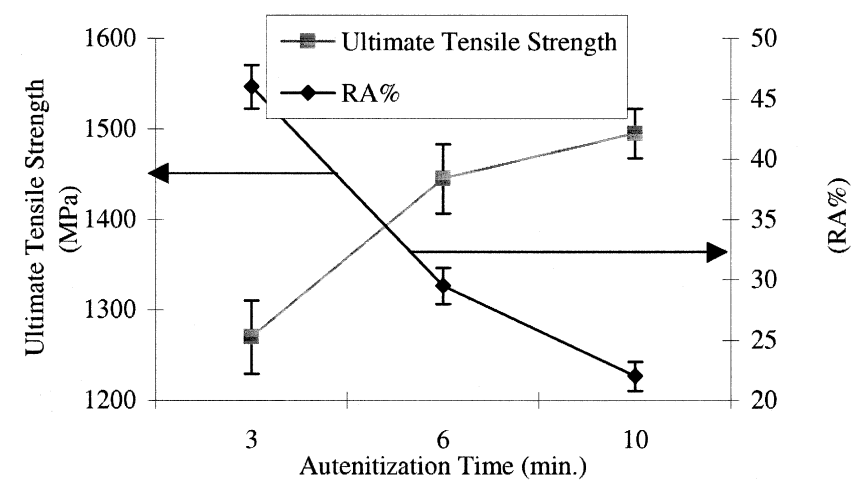

Fig. 8-Tensile test results for steel $11(0.95 \mathrm{C}-1.04 \mathrm{Si}-0.22 \mathrm{~V})$ in $9-\mathrm{mm}$ diameter rods after different austenitization times at $1000{ }^{\circ} \mathrm{C}$. (Isothermal transformation conditions were $600{ }^{\circ} \mathrm{C}$ for $3 \mathrm{~min}$.)

also examined for a fixed austenitization temperature of $1000{ }^{\circ} \mathrm{C}$ and fixed isothermal transformation conditions of $600{ }^{\circ} \mathrm{C}$ for 3 minutes. The properties obtained from $9 \mathrm{~mm}$ rod samples are shown in Figure 8. It appears that 6 minutes of austenitization time gives the best combination of tensile strength and ductility. Although 10 minutes gave a higher tensile strength, the ductility was considered too low to be used. A further decrease of austenitization time below 6 minutes brought about an improvement of the ductility, but with a significant sacrifice of strength.

\section{Comparison of Hardness and Tensile Test Values}

The vickers hardness number can be related to flow strength $\left(\sigma_{y}\right)$ or tensile strength $\left(\sigma_{u}\right)$ by the following equations. ${ }^{[11]}$

$$
\begin{aligned}
& \mathrm{HV}=C_{h v / \sigma y} \cdot \sigma_{y} \\
& \mathrm{HV}=C_{h v / \sigma u} \cdot \sigma_{u}
\end{aligned}
$$

where $C_{h v / \sigma y}$ and $C_{h v / \sigma u}$ are constants and are dependent on the materials tested and the geometry of the indenter. ${ }^{[15]}$ Some results of hardness and tensile test measurements carried out on laboratory steels $9(0.96 \mathrm{C}-0.96 \mathrm{Si}-0.2 \mathrm{~V})$ and 12 (1.05C-1.02Si-0.19V) and for the larger-scale heat of steel 


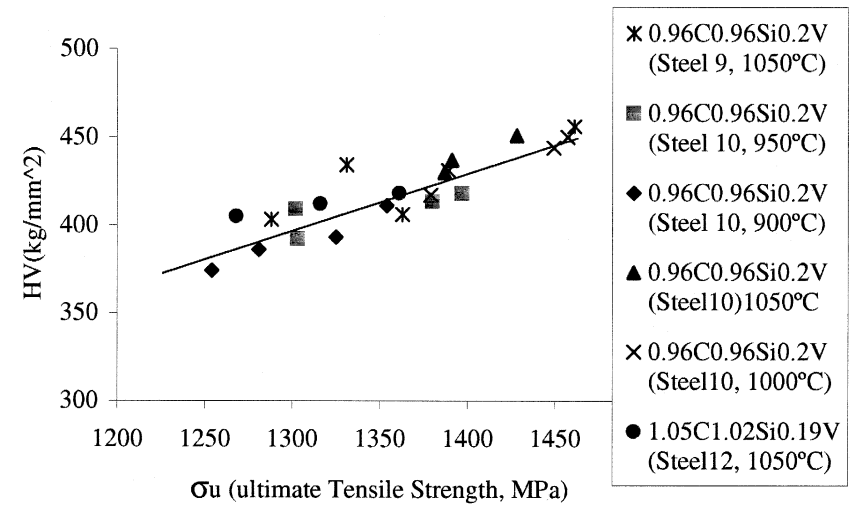

Fig. 9-Relationship between hardness values and tensile strength of steels 9 (0.96C-0.96Si-0.2V), $10(0.96 \mathrm{C}-0.96 \mathrm{Si}-0.2 \mathrm{~V})$ and $12(1.05 \mathrm{C}-1.02 \mathrm{Si}-$ $0.19 \mathrm{~V})$ austenitized at various temperatures for $10 \mathrm{~min}$.

$10(0.93 \mathrm{C}-1.02 \mathrm{Si}-0.25 \mathrm{~V})$ are illustrated in Figure 9. The straight line corresponding to Eq. [2] is also shown. From the data, the mean value of $C_{h v / \sigma y}$ is $4.39 \pm 0.460$ if both hardness and strength are expressed in $\mathrm{MPa}$, or $0.448 \pm$ $0.047 \mathrm{~kg} / \mathrm{mm}^{2} / \mathrm{MPa}$ if hardness is expressed in units of $\mathrm{kg} /$ $\mathrm{mm}^{2}$. For $C_{h v / \sigma u}$, the result is $3.0 \pm 0.7$ (or $0.306 \pm 0.07$ $\left.\mathrm{kg} / \mathrm{mm}^{2} / \mathrm{MPa}\right)$.

\section{E. Wire-Drawing Trials}

Wire-drawing trials were carried out using the largerscale heats of steels $10(0.93 \mathrm{C}-1.02 \mathrm{Si}-0.25 \mathrm{~V})$ and $11(0.95 \mathrm{C}-$ $1.04 \mathrm{Si}-0.22 \mathrm{~V})$. The results of the trials are summarized in Table II. The highest tensile strength was $2540 \mathrm{MPa}$, obtained in wire drawn from 11.5-mm-diameter feed-in stock of steel $10(0.93 \mathrm{C}-1.02 \mathrm{Si}-0.25 \mathrm{~V})$. The isothermal transformation temperature was $600{ }^{\circ} \mathrm{C}$ and the austenitization temperature was $1000^{\circ} \mathrm{C}$. The excellent tensile strength was accompanied by a high reduction of area at fracture of the initial rod (33 pct). After austenitization at the higher temperature of $1050{ }^{\circ} \mathrm{C}$, the reduction in area at fracture of the initial rod was less satisfactory $(17 \mathrm{pct})$. As the austenitization temperature was decreased to $950{ }^{\circ} \mathrm{C}$ to $900{ }^{\circ} \mathrm{C}$, the as-drawn tensile strength decreased, but the ductility of the as-drawn wires was very good under these conditions. For example, wires produced from the $9 \mathrm{~mm}$ rod of steel 11 (0.95C-1.04Si-0.22V), drawn to a 90.7 pct reduction, exhibited a strength of $2354 \mathrm{MPa}$, together with a reduction in area of 30 pct in a tensile test. The slight differences in the total reduction during the various drawing trials are among the factors causing different tensile strengths at the same austenitizing temperature, because the overall refinement of the microstructure will vary correspondingly. ${ }^{[16]}$

\section{DISCUSSION}

The salient features of the current work are the dependence of the mechanical properties of ultrahigh-carbon pearlitic steels on carbon content, alloying additions, microstructure, and isothermal transformation temperature. The combined addition of vanadium and silicon does not only strengthen the pearlite, but also suppresses the formation of continuous grain-boundary cementite, so that the ultrahigh-carbon pearlite can be drawn into high-strength wire. In order to obtain an optimum combination of high strength and ductility, the alloying additions, isothermal transformation temperatures, and drawing routes need to be carefully controlled. We shall discuss each of these variables in turn.

\section{A. Effects of Alloy Composition on Strength}

At a fixed transformation temperature, the hardness values $\mathrm{HV}$ are a function of the alloy element concentrations:

$$
\mathrm{HVCC}=f\left(C_{1}, C_{2} \ldots C_{i} \ldots\right)
$$

where $C_{i}$ is the concentration of alloying element $i$. Over a limited range of compositions, Eq. [3] can be expressed as a Taylor series:

$$
\mathrm{HVC}=C_{0}+\Sigma \mathrm{HV}_{i} C_{i}+\Sigma \Sigma \mathrm{HV}_{i k} C_{i} C_{k}+
$$

where $C_{0}, \mathrm{HV}_{i}, \mathrm{HV}_{i k}$, etc. are constants.

Provided that $C_{i} C_{k}$ is small, the higher-order terms can be omitted and a multiple linear regression technique can be used to fit an expression of the form

$$
\begin{aligned}
\mathrm{HVC} & =C_{0}+\mathrm{HV}_{\mathrm{C}}\left(\text { pet C) }+\mathrm{HV}_{\mathrm{Mn}}(\text { pet Mn })\right. \\
& +\mathrm{HV}_{\mathrm{Si}}(\text { pet Si })+\mathrm{HV}_{\mathrm{V}}(\text { pet V })
\end{aligned}
$$

A similar approach was previously used to estimate the hardening effects of various kinds of alloying elements on tempered martensite ${ }^{[17]}$ and, more recently, to summarize alloy addition effects on the tensile strength of continuously cooled vanadium-free steels. ${ }^{[18]}$ Table III shows the results for the present series of alloys. Because the variation in Mn levels between the different steels studied in this work was very small, the regression analysis does not produce a reliable value for the coefficient $\mathrm{HV}_{\mathrm{Mn}}$. Therefore, in Table III, the terms $C_{0}$ and $\mathrm{HV}_{\mathrm{Mn}}$ (pct $\mathrm{Mn}$ ) in Eq. [5] have been

\begin{tabular}{|c|c|c|c|c|c|c|c|}
\hline $\begin{array}{c}\text { Feed-In Rod } \\
\text { Diameter } \\
(\mathrm{mm}) / \text { Steel } \\
\text { Number }\end{array}$ & $\begin{array}{l}\text { Austenitization } \\
\text { Temperature } \\
\left({ }^{\circ} \mathrm{C}\right)\end{array}$ & $\begin{array}{c}\text { Isothermal } \\
\text { Transformation } \\
\text { Temperature } \\
\left({ }^{\circ} \mathrm{C}\right)\end{array}$ & $\begin{array}{l}\text { Reduction-in-Area } \\
\text { at Fracture before } \\
\text { Drawing (Pct) }\end{array}$ & $\begin{array}{l}\text { Ultimate Tensile } \\
\text { Strength before } \\
\text { Drawing (Mpa) }\end{array}$ & $\begin{array}{l}\text { Ultimate Tensile } \\
\text { Strength after } \\
\text { Drawing (MPa) }\end{array}$ & $\begin{array}{l}\text { Final Wire } \\
\text { Diameter } \\
(\mathrm{mm})\end{array}$ & $\begin{array}{l}\text { Total } \\
\text { Reduction } \\
\text { (Pct) }\end{array}$ \\
\hline $11.5 / 10$ & 1000 & 600 & 33 & 1449 & 2540 & 3.35 & 91.5 \\
\hline $11.5 / 10$ & 950 & 600 & 44 & 1380 & 2273 & 3.35 & 91.5 \\
\hline $10 / 10$ & 1050 & 600 & 17 & 1518 & 2450 & 3.10 & 90.4 \\
\hline $10 / 10$ & 1000 & 600 & 27 & 1495 & 2389 & 3.10 & 90.4 \\
\hline $9 / 11$ & $950-900$ & 600 & 25 & 1410 & 2354 & 2.75 & 90.7 \\
\hline
\end{tabular}
grouped together in a single term, $C$. Clearly, the levels of carbon and vanadium have by far the largest effects on

Table II. Mechanical Properties of Drawn Steels with Different Feed-In Diameters 
Table III. Parameters from Regression Analysis in Relationship of $\mathrm{HV} \subset / 20=\mathbf{C}+\mathbf{H V}_{\mathrm{C}}($ Pct $\mathrm{C})+\mathbf{H V}_{\mathrm{Si}}$ $($ Pct Si $)+\mathbf{H V}_{\mathbf{V}}($ Pet V)

\begin{tabular}{ccccc}
\hline $\begin{array}{c}\text { Isothermal } \\
\begin{array}{c}\text { Transformation } \\
\text { Temperature } \\
\left({ }^{\circ} \mathrm{C}\right)\end{array}\end{array}$ & $\begin{array}{c}\mathrm{C} \\
\left(\mathrm{kg} / \mathrm{mm}^{2}\right)\end{array}$ & $\begin{array}{c}\mathrm{HV}_{\mathrm{C}} \\
\left(\mathrm{kg} / \mathrm{mm}^{2}\right)\end{array}$ & $\begin{array}{c}\mathrm{HV}_{\mathrm{Si}} \\
\left(\mathrm{kg} / \mathrm{mm}^{2}\right)\end{array}$ & $\begin{array}{c}\mathrm{HV}_{\mathrm{V}} \\
\left(\mathrm{kg} / \mathrm{mm}^{2}\right)\end{array}$ \\
\hline 550 & $145 \pm 27$ & $247 \pm 33$ & $22 \pm 9$ & $258 \pm 31$ \\
630 to 635 & $167 \pm 30$ & $174 \pm 37$ & $31 \pm 10$ & $230 \pm 35$ \\
650 & $151 \pm 35$ & $156 \pm 42$ & $42 \pm 11$ & $291 \pm 40$ \\
\hline
\end{tabular}

properties, with silicon being of less importance. The two principal limitations on the use of this approach for the present series of steels have been mentioned earlier. At low transformation temperatures, there is evidence that the effects of combined silicon plus vanadium additions are greater than the sum of the effects of these elements added individually. Clearly, under these conditions, the cross term $C_{\mathrm{Si}} C_{\mathrm{V}}$ is significant and positive in sign. Also, an apparent saturation in strengthening occurs at the highest carbon and vanadium levels, probably due to incomplete dissolution of vanadium carbide during austenitization. This effect is difficult to incorporate in the aforementioned framework, but the cross term $C_{\mathrm{C}} C_{\mathrm{V}}$ could be regarded as significant and negative in sign.

1. Effects of carbon

The parameter $\mathrm{HV}_{\mathrm{C}}$ reflects the two main changes that take place when the carbon concentration is altered. The volume fraction of the strengthening cementite phase changes, but in addition to this, there is an effect on the pearlite interlamellar spacing. In view of this, earlier measurements of isothermal transformation temperature $(T) v s$ interlamellar spacing $(\lambda)$, reported in Reference 12, were subjected to analysis as shown in Table IV and Figure 10(a). The figure is plotted as $T v s 1 / \lambda$, because $T$ and $\lambda$ are considered to obey the equation ${ }^{[19]}$

$$
T=A_{1}-B / \lambda
$$

where $A_{1}$ is the equilibrium austenite decomposition temperature, $B=A_{1} c \sigma_{\alpha / \mathrm{cm}} / \rho \Delta H v, \sigma_{\alpha / \mathrm{cm}}$ is the ferrite/cementite interfacial energy, $\Delta H v$ is the change of enthalpy per unit volume between the austenite and pearlite, $\rho$ is the density, and $c$ is a constant that is between $3 / 2$ and 3 , depending on the model used to develop the equation. ${ }^{[19,20,21]}$ The data in Figure 10(a) indicate that increasing the carbon content from 0.84 to 0.97 pct decreases the interlamellar spacing in 1.0 pct $\mathrm{Si}-0.1$ pct V steels (steels 3 and 8 ) at the same isothermal transformation temperature by about 20 to 25 pct. Assuming that a Hall-Petch-type relationship exists between strength and interlamellar spacing, the reduction in spacing would largely account for the observed increment of $10 \mathrm{pct}$ in hardness produced by this increase in carbon content (Figure $3(b)$ ), with the increase in volume fraction of cementite being a secondary factor.

\section{Effects of vanadium}

Table III demonstrates that vanadium has the strongest strengthening effect among all the alloy elements considered. Additions of this element strengthen pearlite mainly by the formation of precipitates in the ferrite phase. At low transformation temperatures, vanadium may strengthen the ferrite by forming very small clusters with carbon, where little vanadium carbide precipitation can be detected. At relatively high transformation temperatures, where vanadium carbides are detectable by both TEM and FIM/AP, the strengthening effects should be largely attributable to classical precipitation strengthening. ${ }^{[7,22]}$ Using the values of $C_{h v / \sigma u}$ and $H V_{V}$ in Table III, $0.1 \mathrm{wt}$ pct vanadium can be shown to increase tensile strength by 74 to $94 \mathrm{MPa}$, depending on the transformation temperature. These values are of the same magnitude as those obtained by other authors (e.g., 94 to $124 \mathrm{MPa}$ with $0.1 \mathrm{wt}$ pct vanadium additions, according to Kirkcaldy ${ }^{[18]}$ ).

When the variation of pearlite interlamellar spacing with vanadium concentration level was analyzed statistically, no significant trend was found. In the plots of pearlite spacing $v s$ transformation temperature (Figure 10(a)), the behavior of the 1.05 pct C-1.02 pct Si-0.19 pct V steel (steel 12) was anomalous, in that the curve of reciprocal spacing $v \mathrm{~s}$ temperature intersected the equivalent curves for other steels. This indicates a possible effect of increasing vanadium levels on the transformation process in ultrahigh-carbon steels, but the nature of the processes involved is not clear.

\section{Effects of silicon}

Silicon has the lowest strengthening effect among the alloy elements considered. As silicon is detected mainly in ferrite in such steels, ${ }^{[12]}$ its strengthening mainly relies on a solid-solution hardening mechanism. Such a strengthening effect has been reported by several authors either in pure iron $^{[23,24]}$ or in pearlite. ${ }^{[18,25,26]}$ In this work, the solid-solution strengthening in ferrite by silicon affects mechanical properties by almost an order of magnitude less than the strengthening by vanadium. This may be the reason why increasing the addition of silicon from 0.32 to 0.85 pct was reported previously not to enhance the strength levels of pearlite following patenting. ${ }^{[14,27]}$ However, the current work emphasizes the effect of silicon in suppressing the formation of

Table IV. Pearlite Spacings (nm) of Selected Steels

\begin{tabular}{|c|c|c|c|c|c|c|}
\hline $\begin{array}{c}\text { Spacimen } \\
\text { Number }\end{array}$ & Steel 3 & $\begin{array}{c}0.84 \mathrm{C} 1.01 \\
\mathrm{Si} 0.1 \mathrm{~V}\end{array}$ & Steel 8 & $\begin{array}{c}0.97 \mathrm{C} 0.98 \\
\mathrm{Si} 0.1 \mathrm{~V}\end{array}$ & Steel 12 & $\begin{array}{c}1.05 \mathrm{C} 1.02 \\
\mathrm{Si} 0.19 \mathrm{~V}\end{array}$ \\
\hline $\begin{array}{c}\text { Transformation } \\
\text { Temperature } \\
\left({ }^{\circ}\right) \\
\end{array}$ & $\begin{array}{l}\text { Spacings } \\
(\mathrm{nm})\end{array}$ & Error $(\mathrm{nm})$ & $\begin{array}{c}\text { Spacings } \\
(\mathrm{nm})\end{array}$ & Error $(\mathrm{nm})$ & $\begin{array}{c}\text { Spacings } \\
(\mathrm{nm})\end{array}$ & Error $(\mathrm{nm})$ \\
\hline $\begin{array}{l}550 \\
580 \\
635 \\
650\end{array}$ & $\begin{array}{l}105 \\
135 \\
156 \\
199\end{array}$ & $\begin{array}{l}4 \\
5 \\
4 \\
5\end{array}$ & $\begin{array}{r}86 \\
95 \\
123 \\
150\end{array}$ & $\begin{array}{r}8 \\
12 \\
2 \\
5\end{array}$ & $\begin{array}{r}94 \\
101 \\
118 \\
129\end{array}$ & $\begin{array}{l}5 \\
6 \\
6 \\
4\end{array}$ \\
\hline
\end{tabular}




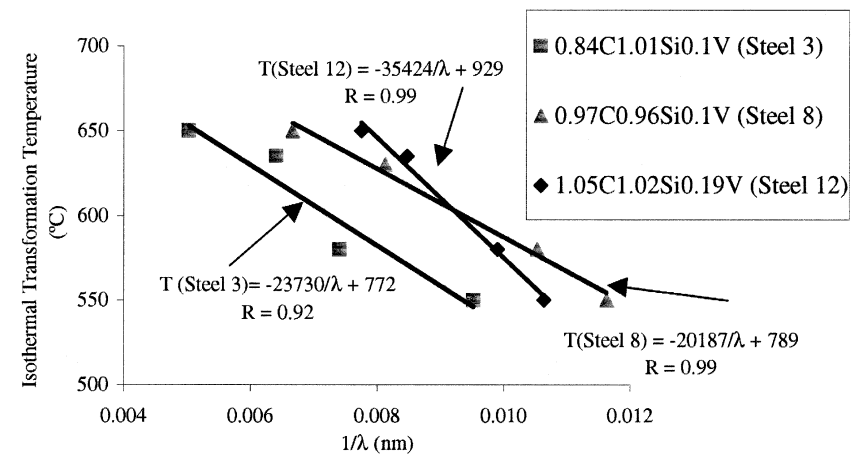

(a)

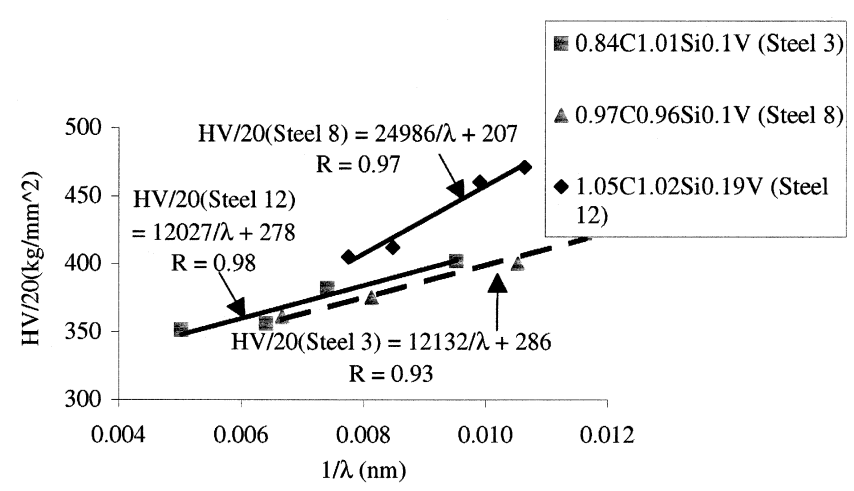

(b)

Fig. 10-Heat treatment and microstructure on hardness of steels $3(0.84 \mathrm{C}$ 1.01Si-0.1V), $8(0.97 \mathrm{C}-0.98 \mathrm{Si}-0.1 \mathrm{~V})$, and $12(1.05 \mathrm{C}-1.02 \mathrm{Si}-0.19 \mathrm{~V})$. The steels were austenitized at $1050{ }^{\circ} \mathrm{C}$ for $10 \mathrm{~min}$ before isothermal transformation at various temperatures for $3 \mathrm{~min}$. The linearity $R$ is used to describe how the data are close to a straight line. The data lie on a straight line if $R=1$. (a) Relationship between isothermal transformation temperatures and reciprocal interlamellar spacing. (b) Relationship between hardness and reciprocal interlamellar spacing.

embrittling grain-boundary cementite networks. Thus, additions of this element are more beneficial to the overall properties of ultrahigh-carbon steels than might be expected simply from consideration of solid-solution strengthening effects. Also, as discussed earlier, a beneficial synergistic effect between silicon and vanadium exists at lower transformation temperatures. No significant effect of silicon concentration on pearlite interlamellar spacings was found.

\section{B. Effects of Transformation Temperature on Strength}

Among the various parameters used to describe pearlitic microstructures, interlamellar spacing is found to be the most important one for determining the tensile strength. ${ }^{[28]}$ It is also found that the hardness values can be related to the tensile strength, as shown in the previous section. Therefore, using Eq. [2] and a relationship between the tensile strength and $\lambda$ value of the pearlite, ${ }^{[29,30,31]}$

$$
\sigma_{u}=\sigma_{0}+K_{u} \lambda^{-m}
$$

a connection can be established between the hardness values and interlamellar spacing: ${ }^{[12,31]}$

$$
\mathrm{HV}=\mathrm{HV}_{0}+K_{h} \lambda^{-m}
$$

where $\mathrm{HV}_{0}=C_{h v / \sigma u} \cdot \sigma_{0}, \sigma_{0}$ being the strength of ferrite; and $K_{h}=C_{h v / \sigma u} K_{u}, K_{u}$ being a constant related to the strength of the dislocation barriers provided by the carbide/ferrite interfaces. The exponent $m$ is generally considered to be 0.5 or 1 . When $m=0.5$ Eq. [7] becomes the Hall-Petch relationship. ${ }^{[32,33]}$ However, a value of $m=1$ is generally preferred, because a negative value of $\sigma_{0}$ is sometimes obtained when the Hall-Petch relationship is employed. Data on the hardness $v s$ the reciprocal of interlamellar spacing for selected steels are shown in Figure 10(b). The parameters in Eq. [8] for several alloyed steels were obtained by a linear regression method and are also shown in the figure. Steel 12 (1.05C-1.02Si-0.19V) has a significantly higher value of $K_{h}$ than the other steels studied, presumably because of its combination of very high carbon, vanadium, and silicon contents.

Combining Eqs. [6] and [8], we obtain

$$
\mathrm{HV}=\mathrm{HV}_{0}+K_{h v} \Delta T^{m}
$$

where $K_{h v}=C_{h v / \sigma u} K_{u} / B^{m}$, and $\Delta T=A-T$. Thus, the Vickers hardness numbers can be related to undercooling by the simple Eq. [9].

If $m=1$, then, after substituting $\Delta T$ with $A_{1}-T$, Eq. [9] becomes

$$
\mathrm{HV}=K_{0}-K_{h v} T
$$

where $K_{0}=\mathrm{HV}_{0}+K_{h v} A_{1}$.

From Eq. [10], it is clear that as $T$ increases, the hardness value decreases, as shown in Figures 1 through 3 . The values of $\mathrm{HV}_{0}$ and $K_{h v}$ were calculated by regression and are listed in Tables V and VI, corresponding to $m=0.5$ and 1 , respectively.

Using the values of $B$ obtained from analysis of the data shown in Figure 10(a), the values of $K_{u}$ when $m=1$ are calculated to be

$0.0387 \mathrm{~N} / \mathrm{mm}$ for steel $3(0.84 \mathrm{C}-1.10 \mathrm{Si}-0.1 \mathrm{~V})$,

$0.0396 \mathrm{~N} / \mathrm{mm}$ for steel $8(0.97 \mathrm{C}-0.98 \mathrm{Si}-1 \mathrm{~V})$, and

$0.0808 \mathrm{~N} / \mathrm{mm}$ for steel 12 (1.05C-1.02Si-0.19V).

These values agree reasonably well with those reported by previous authors for the flow stress of plain-carbon steels (e.g., $0.060 \mathrm{~N} / \mathrm{mm}$ in $0.80 \mathrm{C}-0.84 \mathrm{Mn}-0.17 \mathrm{Si}$, according to Dollar et al. $\left.{ }^{[34]}\right)$. If $m$ equals 0.5 , the values of $K_{u}$ are

$5.4 \mathrm{Nmm}^{-3 / 2}$ for steel $3(0.84 \mathrm{C}-1.10 \mathrm{Si}-0.1 \mathrm{~V})$,

$6.1 \mathrm{Nmm}^{-3 / 2}$ for steel $8(0.97 \mathrm{C}-0.98 \mathrm{Si}-0.1 \mathrm{~V})$, and

$10.0 \mathrm{Nmm}^{-3 / 2}$ for steel 12 (1.05C-1.02Si-0.19V).

These values are also of similar magnitude to those reported by previous authors for plain-carbon steels (e.g., 7.83 $\mathrm{Nmm}^{-3 / 2}$, according to Dollar et al. $\left.{ }^{[34]}\right)$.

The effect of alloy elements on $\mathrm{HV}_{0}$ and $K_{h v}$ can also be examined using the data in Tables V and VI. There is a clear trend in the values of $\mathrm{HV}_{0}$, the parameter that measures the strength of the ferrite phase. The plain-carbon steels have the lowest values, the silicon steel values are slightly higher, and the vanadium steel values are higher again, with the highest vanadium content giving the highest overall value of $\mathrm{HV}_{0}$. This is consistent with a progressive increase in the strength of ferrite, first by solid-solution hardening due to silicon and then by precipitation strengthening due to vanadium carbide formation. In contrast to the behavior of the $\mathrm{HV}_{0}$ parameter, there are no clear trends in the variation of $K_{h v}$ with alloy composition. The different vanadium-containing steels exhibit some of the lowest, as well as the highest, values of $K_{h v}$, and the values for plain-carbon and silicon-containing steels are also variable. Because the $K_{h v}$ parameter is complex, involving both thermodynamic terms 
Table V. Estimated Magnitude of $\mathbf{H V}_{0}$ and $K_{h v}$ Values in Relation between Hardness and Isothermal Transformation Temperatures $(m=0.5)$

\begin{tabular}{|c|c|c|c|c|}
\hline Steel Number & $\begin{array}{c}\mathrm{HV}_{0} \\
\left(\mathrm{~kg} / \mathrm{mm}^{2}\right)\end{array}$ & $\begin{array}{c}K_{h v} \\
\left(\mathrm{~kg} / \mathrm{mm}^{2} / \mathrm{K}^{0.5}\right)\end{array}$ & $\begin{array}{l}\text { Linearity } \\
(R)^{*}\end{array}$ & $\begin{array}{c}\text { Austenitization } \\
\text { Temperature } \\
\left({ }^{\circ} \mathrm{C}\right)\end{array}$ \\
\hline $1(0.76 C)$ & 138 & 15.3 & 0.98 & 1050 \\
\hline $2(0.81 \mathrm{C}-0.96 \mathrm{Si})$ & 239 & 9.3 & 0.93 & 1050 \\
\hline $3(0.84 \mathrm{C}-1.01 \mathrm{Si}-0.1 \mathrm{~V})$ & 254 & 10.7 & 0.84 & 1050 \\
\hline $4(0.79 \mathrm{C}-0.2 \mathrm{~V})$ & 288 & 7.9 & 0.90 & 1050 \\
\hline $5(0.82 \mathrm{C}-0.92 \mathrm{Si}-0.2 \mathrm{~V})$ & 253 & 13.3 & 0.81 & 1050 \\
\hline $6(0.95 C)$ & 187 & 10.0 & 0.99 & 1050 \\
\hline $7(0.95 \mathrm{C}-1.04 \mathrm{Si})$ & 267 & 10.7 & 0.97 & 1050 \\
\hline $8(0.97 \mathrm{C}-0.98 \mathrm{Si}-0.1 \mathrm{~V})$ & 244 & 13.2 & 0.99 & 1050 \\
\hline $10(0.93 \mathrm{C}-1.02 \mathrm{Si}-0.25 \mathrm{~V})$ & 348 & 8.7 & 0.93 & 1050 \\
\hline $10(0.93 \mathrm{C}-1.02 \mathrm{Si}-0.25 \mathrm{~V})$ & 303 & 12.2 & 0.98 & 1000 \\
\hline $10(0.93 \mathrm{C}-1.02 \mathrm{Si}-0.25 \mathrm{~V})$ & 311 & 9.0 & 0.90 & 950 \\
\hline $10(0.93 \mathrm{C}-1.02 \mathrm{Si}-0.25 \mathrm{~V})$ & 253 & 12.7 & 0.96 & 900 \\
\hline $12(1.05 \mathrm{C}-1.02 \mathrm{Si}-0.19 \mathrm{~V})$ & 264 & 16.3 & 0.86 & 1050 \\
\hline
\end{tabular}

*The linearity is used to describe how the data are close to a straight line. The data lie on a straight line if $R=1$.

Table VI. Estimated Magnitude of $\mathbf{H V}_{\mathbf{0}}$ and $\mathbf{K}_{\mathrm{hv}}$ Values in Relation between Hardness and Isothermal Transformation Temperatures $(m=1)$

\begin{tabular}{|c|c|c|c|c|}
\hline Steel Number & $\begin{array}{c}\mathrm{HV}_{0} \\
\left(\mathrm{~kg} / \mathrm{mm}^{2}\right)\end{array}$ & $\underset{\left(\mathrm{kg} / \mathrm{mm}^{2} / \mathrm{K}\right)}{\mathrm{K}_{\mathrm{HV}}}$ & $\begin{array}{c}\text { Linearity } \\
(R)\end{array}$ & $\begin{array}{c}\text { Austenitization } \\
\text { Temperature } \\
\left({ }^{\circ} \mathrm{C}\right)\end{array}$ \\
\hline $1(0.76 C)$ & 216 & 0.73 & 0.99 & 1050 \\
\hline $2(0.81 \mathrm{C}-0.96 \mathrm{Si})$ & 288 & 0.43 & 0.93 & 1050 \\
\hline $3(0.84 \mathrm{C}-1.01 \mathrm{Si}-\mathrm{O} .1 \mathrm{~V})$ & 309 & 0.50 & 0.88 & 1050 \\
\hline $4(0.79 \mathrm{C}-0.2 \mathrm{~V})$ & 329 & 0.37 & 0.89 & 1050 \\
\hline $5(0.82 \mathrm{C}-0.92 \mathrm{Si}-0.2 \mathrm{~V})$ & 324 & 0.61 & 0.82 & 1050 \\
\hline $6(0.95 C)$ & 270 & 0.75 & 0.99 & 1050 \\
\hline $7(0.95 \mathrm{C}-1.04 \mathrm{Si})$ & 324 & 0.48 & 0.96 & 1050 \\
\hline $8(0.97 \mathrm{C}-0.98 \mathrm{Si}-0.1 \mathrm{~V})$ & 315 & 0.60 & 0.99 & 1050 \\
\hline $10(0.93 \mathrm{C}-1.02 \mathrm{Si}-0.25 \mathrm{~V})$ & 394 & 0.40 & 0.92 & 1050 \\
\hline $10(0.93 \mathrm{C}-1.02 \mathrm{Si}-0.25 \mathrm{~V})$ & 369 & 0.56 & 0.97 & 1000 \\
\hline $10(0.93 \mathrm{C}-1.02 \mathrm{Si}-0.25 \mathrm{~V})$ & 359 & 0.41 & 0.88 & 950 \\
\hline $10(0.93 \mathrm{C}-1.02 \mathrm{Si}-0.25 \mathrm{~V})$ & 321 & 0.59 & 0.97 & 900 \\
\hline $12(1.05 \mathrm{C}-1.02 \mathrm{Si}-0.19 \mathrm{~V})$ & 345 & 0.70 & 0.88 & 1050 \\
\hline
\end{tabular}

and mechanical properties (Eqs. [6] and [9]), no simple explanation for its variation seems possible at this stage.

\section{Effects of Wire Drawing on Strength}

The increment of the strength by wire drawing is principally due to the decreasing scale of the pearlite interlamellar spacing. A number of authors have treated the problem of drawing, which involves the codeformation of phases as a problem of similitude, in which the spacing at strain $(\varepsilon)$ is proportional to the external diameter $\left(D_{\varepsilon}\right)$ of the wire or rod at this strain level. Thus, the interlamellar spacings $\lambda_{\varepsilon}$ and $\lambda_{0}$ at the drawing strain $\varepsilon$ and before drawing, respectively, are related by ${ }^{[3,35]}$

$$
\lambda_{\varepsilon}=\lambda_{0}\left(D_{\varepsilon} / D_{0}\right)
$$

where $D_{0}$ is the external diameter of the wire or rod at zero strain.

To a first approximation, the strength $\sigma_{u}$ obtained at $\lambda_{\varepsilon}$ can be described by combining Eqs. [7] and [11] and assuming that $m=0.51 .0$ :

$$
\sigma_{u}=\sigma_{o}+K_{u} \lambda_{0}^{-1 / 2}\left(D_{0} / D_{\varepsilon}\right)^{1 / 2}
$$

or

$$
\sigma_{u}=\sigma_{o}+K_{u} \lambda_{0}\left(D_{0} / D_{\varepsilon}\right)
$$

The $\sigma_{u}$ values for steel $11(0.95 \mathrm{C}-1.04 \mathrm{Si}-0.22 \mathrm{~V})$ are plotted with respect to $\left(D_{0} / D_{\varepsilon}\right)^{1 / 2}$ and $\left(D_{0} / D_{\varepsilon}\right)$ in Figure 11 . In each case, a good straight-line fit is obtained. An estimated value for $\sigma_{0}$ is $406 \mathrm{MPa}$, and the estimate for $K_{u} \lambda_{0}{ }^{-1 / 2}$ is $1,006 \mathrm{MPa}$, if $m=0.5$. Plain-carbon eutectoid steels gave equivalent $\sigma_{0}$ and $K_{u} \lambda_{0}{ }^{-1 / 2}$ values of 72 and $1304 \mathrm{MPa}$, respectively. ${ }^{[36]}$ The measured $\lambda_{0}$ value for steel 11 is $100 \pm 10 \mathrm{~nm}$. Therefore, $K_{u}$ for this steel is $10.0 \mathrm{Nmm}^{-3 / 2}$, which is the same as the value obtained in the previous section for steel $12(1.05 \mathrm{C}$ $1.02 \mathrm{Si}-0.19 \mathrm{~V}$ ) when $m=0.5$. Therefore, increasing the carbon content from 0.95 to $1.05 \mathrm{wt}$ pct does not have a significant impact on strengthening the pearlite by increasing the barriers to dislocation migration in the lamellar structure, consistent with the conclusion drawn from the hardness tests. This also indicates that the extra carbon $(0.1$ wt pct $\mathrm{C})$ 


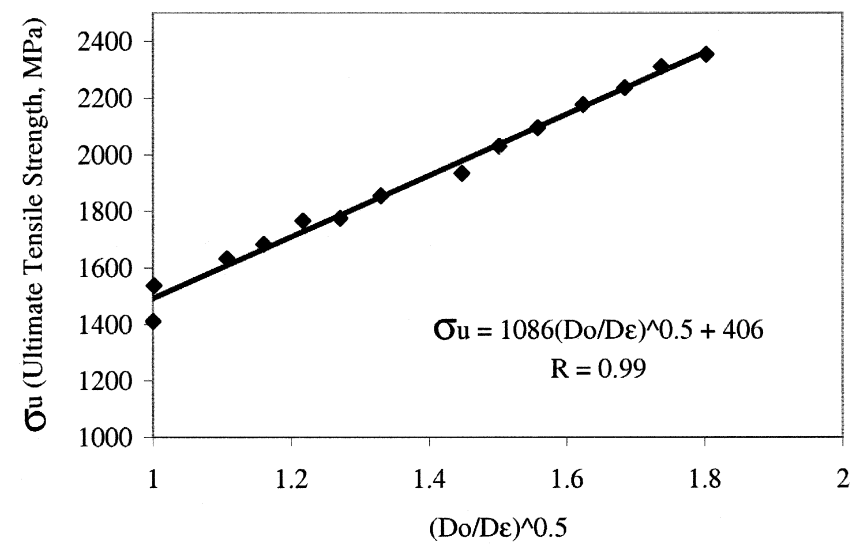

(a)

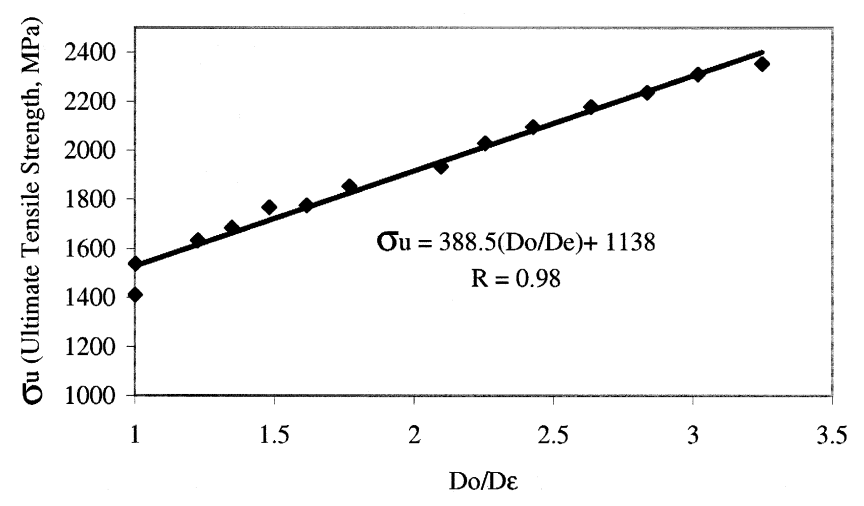

(b)

Fig. 11-Relationship between ultimate tensile strength and $D_{0} / D_{\varepsilon}$ for steel $11(0.95 \mathrm{C}-1.04 \mathrm{Si}-0.22 \mathrm{~V})$ assuming $(a) m=0.5$ and $(b) m=1$. The $R$ is the linearity of the regression fit.

contributes mainly to the formation of grain-boundary cementite, which has a limited contribution to $K_{u}$.

\section{CONCLUSIONS}

1. Vanadium increases the strength of pearlite, mainly by precipitation strengthening of ferrite.

2. Silicon strengthens pearlite mainly by solid-solution strengthening in ferrite. It has a relatively larger strengthening effect at higher isothermal transformation temperatures.

3. At lower transformation temperatures $\left(<600{ }^{\circ} \mathrm{C}\right)$, combined additions of silicon and vanadium give strength increments greater than the sum of those obtained by equivalent separate additions of these elements.

4. Decreasing the austenitization temperature from $1100{ }^{\circ} \mathrm{C}$ to $900{ }^{\circ} \mathrm{C}$ progressively decreases the ultimate tensile strength but increases the ductility significantly in hypereutectoid steels alloyed with vanadium and silicon.

5. Decreasing the isothermal transformation temperature from $650{ }^{\circ} \mathrm{C}$ to $550{ }^{\circ} \mathrm{C}$ increases the tensile strength and hardness by decreasing the interlamellar spacing. Decreasing the isothermal transformation temperature in the same temperature range alters the ductility in hypereutectoid steels alloyed with vanadium and silicon. Optimum properties are obtained for a transformation temperature of $600{ }^{\circ} \mathrm{C}$.
6. The wire-drawing trial demonstrates that good mechanical properties can be obtained from the steels, with optimum composition (0.95C-1.0Si-0.2 wt pct V) and heattreatment conditions determined from laboratory-scale testing. Total reductions in area of 90 pct could be obtained during drawing, leading to final as-drawn tensile strengths of up to $2540 \mathrm{MPa}$ in a 3.3-mm-diameter wire.

\section{ACKNOWLEDGMENTS}

Financial support from the Government of the People's Republic of China, the British Council, and the United States National Science Foundation is gratefully acknowledged. We also thank Haggie Rand Ltd. in South for supplying materials and travel support for $\mathrm{KH}$ and for carrying out the drawing trials reported here.

\section{REFERENCES}

1. I. Ochian, S. Nishida, H. Ohba, and A. Kawana: Wire J. Int., 1993, vol. 26 , p. 50 .

2. I. Ochian, S. Nishida, H. Ohba, and A. Kawana: Tetsu-to-Hagané-J. Iron Steel Inst. Jpn., 1993, vol. 79, pp. 1101-07.

3. K. Han, J.D. Embury, J.R. Sims, L.J. Campbell, H.-J. SchneiderMuntau, V.I. Pantsyrnyi, A. Shikov, A. Nikulin, and A. Vorobieva: Mater. Sci. Eng., 1999, vol. A267, pp. 99-114.

4. M. Carsi, F. Penalba, O.A. Ruano, and O.D. Sherby: Metall. Mater Trans. A, 1997, vol. 28A, pp. 1913-20.

5. K.T. Park, S.K. Cho, and J.K. Choi: Scripta Mater, 1997, vol. 37, pp. 661-66.

6. K. Han, G.D.W. Smith, and D.V. Edmonds: Mater. Sci. Eng., 1995 , vol. A190, pp. 207-14.

7. K. Han, G.D.W. Smith, and D.V. Edmonds: Metall. Mater. Trans. A 1995, vol. 26A, pp. 1617-32.

8. E.R. Morgan and J.C. Shyne: Trans. AIME, 1957, vol. 209, pp. 65-69.

9. A. Karimi Taheri, T.M. Maccagno, and J.J. Jonas: Metall. Mater. Trans. A, 1995, vol. 26A, pp. 1183-94.

10. J. Languillaume, G. Kapelski, and B. Baudelet: Acta Mater, 1997, vol. 45, pp. 1201-12.

11. G.F. Vander Voort: Metallography Principles and Practice, McGrawHill Book Company, London, 1984.

12. K. Han: Ph.D. Thesis, Oxford University, Oxford, United Kingdom, 1992.

13. K. Han: Scripta Metall. Mater, 1993, vol. 28, pp. 699-702.

14. J.R. Franklin, R.R. Preston, and C. Allen: Wire Industry, 1980, pp 958-66.

15. K.L. Johnson: J. Mech. Phys. Solids, 1970, vol. 18, pp. 115-26.

16. J. Toribio and E. Ovejero: Mater. Sci. Eng., 1997, vol. 234, pp. 579-82.

17. R.A. Grange, C.R. Hribal, and L.F. Porter: Metall. Trans. A, 1977, vol. 8 A, pp. $1775-87$.

18. A. Kirkcaldy: The British Independent Steel Producer Association Wire Product Group Technical Conf., Stratford-upon-Avon, 1984, p. 22.

19. C. Zener: Trans. AIME, 1946, vol. 167, p. 550.

20. J.S. Kirkaldy: in Decomposition of Austenite by Diffusional Processes, V.F. Zackay and H.I. Aaronson, eds., Interscience, New York, NY, 1962, p. 197

21. M.P. Puls and J.S. Kirkaldy: Metall. Trans., 1972, vol. 3, pp. 2777-96

22. S.A. Parsons and D.V. Edmonds: Mater. Sci. Technol., 1987, vol. 3, pp. 894-904.

23. T.D. Yensen: Trans. AIEE, 1924, vol. 43, p. 145

24. C.E. Racy and M. Gensamer: Trans. ASM, 1944, vol. 32, p. 94.

25. T. Takahashi, M. Nagumo, and Y. Asano: Wire J., 1980, vol. 13 (11), pp. 78-82.

26. I. Ochial, M. Nagumo, T. Amakawa, and T. Takahashi: Wire J. Int., 1983, vol. 16 (7), pp. 72-81.

27. N.Y. Yamakoshi, Y. Nakamura, and T. Kaneda: Wire J., 1977, vol 10 , pp. 36-46.

28. J.M. Hyzak and I.M. Bernstein: Metall. Trans. A, 1976, vol. 7A, pp. 1217-24.

29. A.R. Marder and B.L. Bramfitt: Metall. Trans. A, 1976, vol. 7A, pp. 365-72. 
30. M. Dollar, I.M. Bernstein, M. Daeubler, and A.W. Thompson: Metall. Trans. A, 1989, vol. 20A, pp. 447-51.

31. K.K. Ray and D. Mondal: Acta Metall., 1991, vol. 39 (10), pp. 2201-08.

32. E.O. Hall: Proc. Phys. Soc., 1951, vol. B64, pp. 742-47.

33. N.J. Petch: J. Iron Steel Inst., 1953, vol. 174, p. 25.
34. M. Dollar, I.M. Bernstein, and A.W. Thompson: Acta Metall., 1988, vol. 36, pp. 311-20.

35. J.D. Embury and R.M. Fisher: Acta Metall., 1966, vol. 14, pp. 147-59

36. J. Gil Sevillano: Ph.D. Thesis, Katholieke University Leuven, Belgium, 1972. 


\section{Annotations from 00290A4-2.pdf}

\section{Page 2}

Annotation 1; Label: IPC; Date: 3/20/2001 8:39:54 AM

Author: Please include city location within parentheses.

Annotation 2; Label: IPC; Date: 3/20/2001 8:40:09 AM

Author: Please insert city location.

Annotation 3; Label: IPC; Date: 3/20/2001 8:40:27 AM

Author: Please insert city location.

\section{Page 7}

Annotation 1; Label: IPC; Date: 3/20/2001 8:41:36 AM

Author: Equation 4: Is this a plus symbol (if so, to be deleted) or an intentional positive sign?

\section{Page 11}

Annotation 1; Label: IPC; Date: 3/20/2001 8:42:07 AM

Author: Acknowledgments: South what?

Annotation 2; Label: IPC; Date: 3/20/2001 8:42:28 AM

Author: References 4 and 7: Is "A" correct?

Annotation 3; Label: IPC; Date: 3/20/2001 8:42:53 AM

Author: References 4 and $7:$ Is "A" correct? 


\section{Online Proofing Guidance Page}

\section{FIRST STEP:}

Install Adobe Acrobat Reader if you do not already have this or another Acrobat product installed on your computer. You can do this free of charge by connecting to the Adobe site and following the instructions at:

$$
\text { http://www.adobe.com/products/acrobat/readermain.html }
$$

\section{SECOND STEP:}

Please download and print your PDF file - we recommend that you save this file to disk, rather than opening it from within your Browser.

\section{From a PC:}

1. Right-click on the file/article link.

2. Select "Save Target as"

3. Select a desired location on your computer to save the file to, and click on "Save"

4. Open your PDf file directly with Acrobat Reader or another Acrobat product.

5. Print this file as you normally would with any typical application. Example: Go up to your toolbar, select "File", select "Print".

\section{From a MAC:}

1. Hold the mouse button down over the link.

a. In Internet Explorer, select "Download Link to Disk" from the resulting pop-up menu

b. In Netscape, select "Save this Link as" from the resulting pop-up menu

2. Select a desired location on your computer and click on "Save"

3. Open your PDF file directly with Acrobat Reader or another Acrobat product.

4. Print this file as you normally would with any typical application. Example: Go up to your menu bar, select "File", select "Print".

\section{THIRD STEP:}

Please go through the file you have just printed and thoroughly and clearly mark any revisions you would like to see implemented in your paper. If you have had any changes in phone/fax or e-mail addresses since your paper was submitted, please send us this new information.

\section{FOURTH STEP:}

\section{Your revised paper needs to be faxed or mailed to:}

IPC Communication Services

Attn: Sheryl Dickenson

501 Colonial Drive

St. Joseph, MI 49085

Fax number: 1-616-983-4064

If you have questions regarding your paper in general, you may email or telephone:

IPC Communication Services

Attn: Sheryl Dickenson

Email: sdickens@ipcjci.com

Phone: 1-616-983-7412, ext. 529 